\title{
EVALUATION OF URICOSURIC AGENTS IN CHRONIC GOUT*
}

\author{
BY

\section{A. OGRYZLO AND JOAN HARRISON $\dagger$} \\ From the Department of Medicine, University of Toronto, the Clinical Investigation Unit, \\ Sunnybrook Hospital, and the Medical Service, Toronto General Hospital, Canada
}

Experience gained during the past 7 years with the prolonged administration of probenecid (Pascale, Dubin, and Hoffman, 1952; Talbott, 1953; Gutman and Yü, 1955; Bartels, 1955; Bauer and Singh, 1957) or of salicylates (Marson, 1953, 1954, 1955) has shown that continuous therapy with a uricosuric agent in effective doses, is the only practical method at present available for preventing the complications and morbidity which occur in patients with chronic gout. Subjective and objective improvement have been recorded in nearly all instances where there has been strict adherence to the therapeutic regimen. Attacks of acute gouty arthritis become progressively less frequent and less severe or may cease entirely; chronic joint pain and stiffness gradually improve; and tophaceous urate deposits gradually shrink in size or may be observed to disappear entirely (Yü and Gutman, 1951; Marson, 1952).

The long-term treatment has been directed mainly toward the correction of the hyperuricaemia and reduction of the greatly increased miscible pool of uric acid shown to be present in most patients with established chronic gout (Benedict, Forsham, Roche, Soloway, and Stetten, 1950; Bishop, Rand, and Talbott, 1951; Talbott, 1953; Gutman and Yü, 1955). Although a diet restricted in purines and fat will lower the serum uric acid slightly (Marson, 1953; Gutman and Yü, 1955), dietary restrictions have been only partially successful as a treatment measure (Bauer and Klemperer, 1944; Talbott, 1953; Gutman and Yü, 1955). Practical experience has shown that the correction of the hyperuricaemia and the associated positive urate balance can most readily be accomplished by the administration of

* Presented at the IX International Congress of Rheumatic Diseases, Toronto, Canada, 1957.

$\dagger$ Research Fellow in Arthritis, Clinical Investigation Unit, Sunnybrook Hospital, Toronto. drugs having a uricosuric action. These agents have in common the property of increasing urinary uric acid excretion through their blocking effect on tubular reabsorption (Sirota, Yü, and Gutman, 1952; Yü, Sirota, and Gutman, 1953; Talbott, 1953; Yü and Gutman, 1955). The existing positive urate balance is reversed to a negative balance and the concentration of uric acid in the circulating plasma thereby reduced. To be effective, however, the treatment must be uninterrupted and continued over prolonged periods, perhaps indefinitely. Any sustained reduction in the serum uric acid may result in benefit to the patient, but it has become increasingly apparent that the greatest improvement occurs when the serum uric acid is maintained consistently within the normal range.

A variety of substances having uricosuric action are known to exist, but not all of them are suitable for continuous therapy over prolonged periods. Salicylates, either as sodium salicylate or acetylsalicylic acid, have long been known to exert a potent uricosuric effect when administered in a daily dose of 6 to $8 \mathrm{~g}$., and have been used with impressive results (Jennings, 1937; Marson, 1953). Unfortunately such large doses are generally not well tolerated (Gutman, 1950; Talbott, 1953). Many patients complain of gastric irritation or suffer salicylism during the early weeks of therapy, although with persistent administration a large proportion of these will eventually develop a tolerance to the drug (Marson, 1954). The introduction of probenecid as a uricosuric agent (Gutman, 1950; Gutman and Yü, 1951; Talbott, Bishop, Norcross, and Lockie, 1951 ; Sirota and others, 1952; Bishop and others, 1951), with its lower incidence of side effects and virtual lack of serious toxicity (Talbott, 1953; Gutman, Yü, and Randolph, 1954; Gutman and Yü, 1955; Bartels, 1955; Boger and 
Strickland, 1955; Bauer and Singh, 1957), prompted its use on a broad scale. The administration of 1 to $2 \mathrm{~g}$. daily over prolonged periods, results in a distinct reduction in the serum uric acid, and is accompanied by clinical improvement in most instances. However, in some cases the uricosuric effect is inadequate in the smaller doses, while larger doses may not be well tolerated, and in such circumstances the patient may experience little or no improvement. Phenylbutazone has been shown to have a good uricosuric effect when administered in doses of 0.6 to $1 \mathrm{~g}$. daily (Yü and others, 1953; Bishop and Beecher, 1953; Wyngaarden, 1955), and is also very effective in controlling the acute attacks of gouty arthritis (Kuzell, Schaffarzick, Naugler, Koets, Mankle, Brown, and Champlin, 1955; Wilson, Huffman, and Smyth, 1956). However, its salt retaining properties (Yü and others, 1953; Brodie, Lowman, Burns, and five others, 1954a) and reported toxicity (Kuzell, Schaffarzick, Naugler, Gaudin, Mankle, and Brown, 1954; Kuzell and others, 1955; Mauer, 1955) are a distinct disadvantage and have discouraged to a large extent its use for the treatment of chronic gout (Yü and others, 1953). Recently two new uricosuric agents have been introduced. They are the analogues of phenylbutazone: 4-(phenylthioethyl)-1,2-diphenyl-3,5-pyrazolidinedione (G25671) (Brodie, Yü, Burns, and four others, 1954b; Yü, Paton, Chenkin, Burns, Brodie, and Gutman, 1956) and 4-(phenylsulfoxyethyl)-1,2diphenyl-3,5-pyrazolidinedione (G28315) (Burns, Yü, Ritterband, Perel, Gutman, and Brodie, 1957). Unlike phenylbutazone, these derivatives are of little or no value in the treatment of the acute attacks of gouty arthritis (Yü and others, 1956). Similarly, their analgesic action appears to be lower, although this has not yet been fully assessed. However, they are potent uricosuric agents, possibly superior to probenecid.

\section{Methods}

The present study was undertaken in order to compare a number of uricosuric agents in the treatment of patients with chronic gout. Evaluation was made on the basis of their efficiency in the following respects:

(1) Stimulating an increased excretion of uric acid in the urine;

(2) Lowering the serum uric acid concentration;

(3) Sustained action over prolonged periods;

(4) Prevention of attacks of gouty arthritis;

(5) Toxicity.

In the study were included probenecid (Benemid), phenylbutazone (Butazolidin), thiophenylpyrazoli- dine (G25671), sulfoxyphenylpyrazolidine (G28315), acetylsalicylic acid (Aspirin), and ethyl biscoum- 0 acetate (Tromexan). All of the drugs were administered in divided doses throughout the 24 hours. Many of the patients received courses of more than $\stackrel{?}{+}$ one drug in the period under study. The observations include a number of short-term studies in a $\frac{\bar{\sigma}}{\bar{D}}$ metabolic unit on controlled diets as well as pro- $\frac{\infty}{\Phi}$ longed administration without dietary control, on $\stackrel{\varnothing}{\varnothing}$ the general medical wards or in the out-patient is clinic.

The data shown in Figs 1 to 6 illustrate studies undertaken in the Clinical Investigation Unit, $\vec{\omega}$ under controlled conditions with constant dietary and fluid intake. The diets were designed to maintain optimum weight and excluded foods having a high $\vec{\sigma}$ purine content. Figs 9 to 12 show data obtained $\rightarrow$ on patients in the general medical wards or in the out-patient clinic. The scattergrams, Figs 7 and 8, represent composite data.

Serum and urine uric acid determinations were made by the method of Kern and Stransky (1937). Serum and urine electrolytes were determined by flame photometry. The patients were followed with routine blood counts including haemoglobin, red cell, white cell, differential, and platelet counts and periodic determination of the non-proteig nitrogen. In a number of instances, renal functici studies were carried out, including phenolsulphon? phthalein excretion and intravenous pyelography.

As an index of uricosuric action, a clearance ratio was obtained by dividing the pooled $48-\mathrm{hr}$ urine uric acid value by the serum uric acid value obtained in the middle of each 48-hr period, and expressed in litres of serum cleared per day. This figure approximated closely the true uric acid clearances obtained at periodic intervals in the studies. The clearance ratio does not represent an accurate index of renal function synonymous with absolute renal clearance, but it does provide a useful comparison of the uricosuric action of the different drugs tested.

\section{Results}

An initial comparison was made between $1 \mathrm{~g}$. G25671 daily for 8 days, and $1 \mathrm{~g}$. Benemid daily for 8 days (Fig. 1, opposite). With G25671, the serum uric acid dropped from control values of $10 \mathrm{mg}$. to $4 \cdot 2 \mathrm{mg}$. per cent. in 6 days, whereas with Benemid the decrease was from a control value of $8 \mathrm{mg}$. to a low level of $6.2 \mathrm{mg}$. per cent. in 8 days. It is apparent from the effect on the serum uric acid level, total urinary uric acid excretion, and clearance ratio, that G25671 was considerably more effective as a uricosuric agent than was Benemid. 


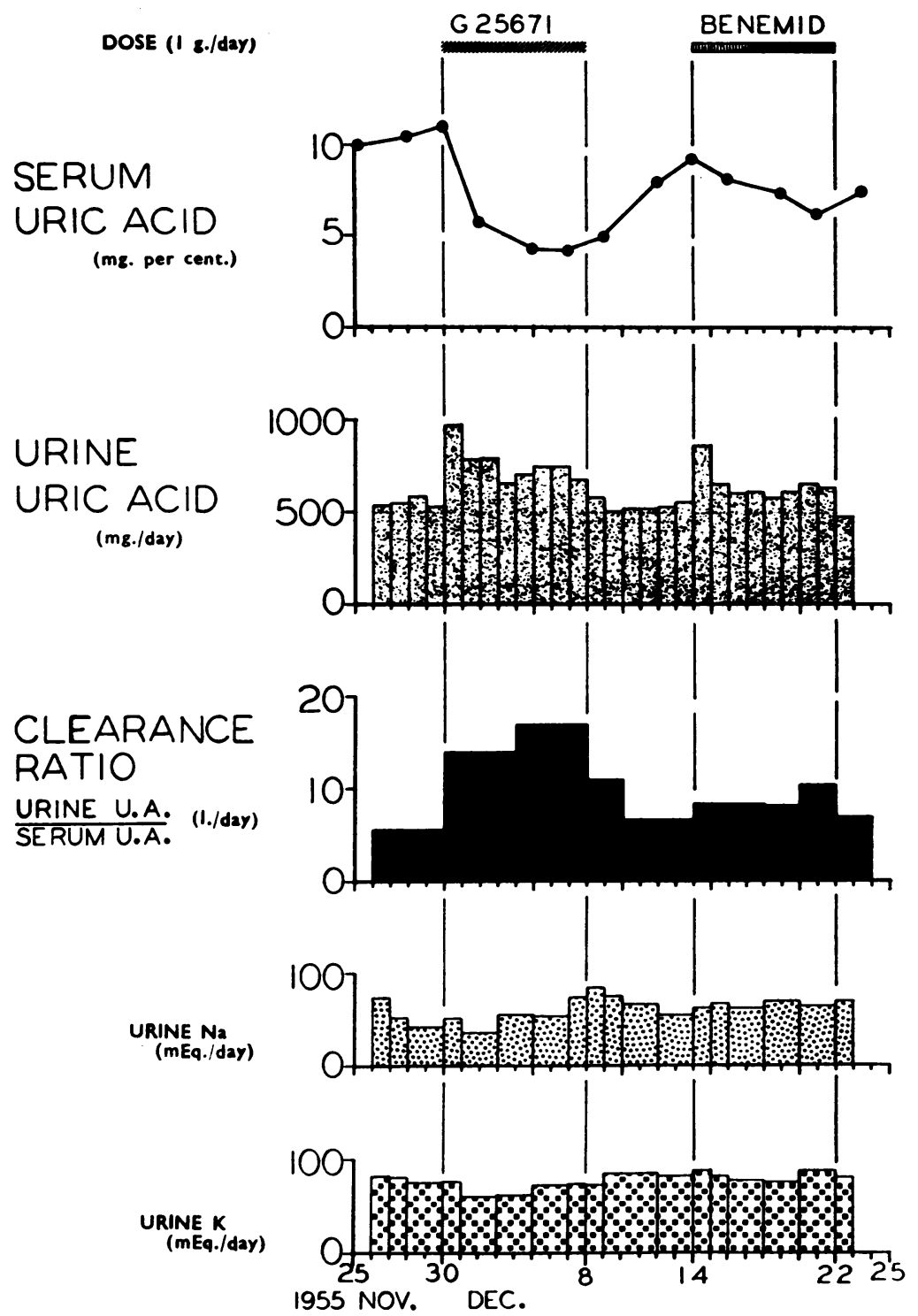

Fig. 1.-Comparison between the uricosuric effects of 1 g. G25671 daily for 8 days and 1 g. Benemid daily for 8 days.

In a second patient (Fig. 2, overleaf), a similar comparison was made between G25671 $1 \mathrm{~g}$. daily for 8 days, and Benemid $2 \mathrm{~g}$. daily for 8 days. With G25671 the serum uric acid dropped from 10 to $5 \cdot 7$ mg. per cent. in 6 days, while with Benemid the decrease was from 9.9 to $6.8 \mathrm{mg}$. per cent. after 5 days. Again, on the basis of the serum uric acid levels, total urinary uric acid excretion, and clearance ratio, G25671 exhibited greater uricosuric activity.

In a third patient (Fig. 3, overleaf, p. 429), a comparison was made between $3 \mathrm{~g}$. Benemid daily for
8 days, and 1 g. G25671 daily for 8 days. With Benemid the serum uric acid dropped from a control value of $10.9 \mathrm{mg}$. to $4.3 \mathrm{mg}$. per cent. in 7 days, while with G25671 the values dropped from 9.5 to $4.1 \mathrm{mg}$. per cent. in 4 days. The increase in total urinary uric acid excretion and the clearance ratio were approximately equal. In these three studies, therefore, it was not until the dose of Benemid was raised to $3 \mathrm{~g}$. daily, that a degree of uricosuric action was obtained comparable to that resulting from $1 \mathrm{~g}$. daily of the G25671. 


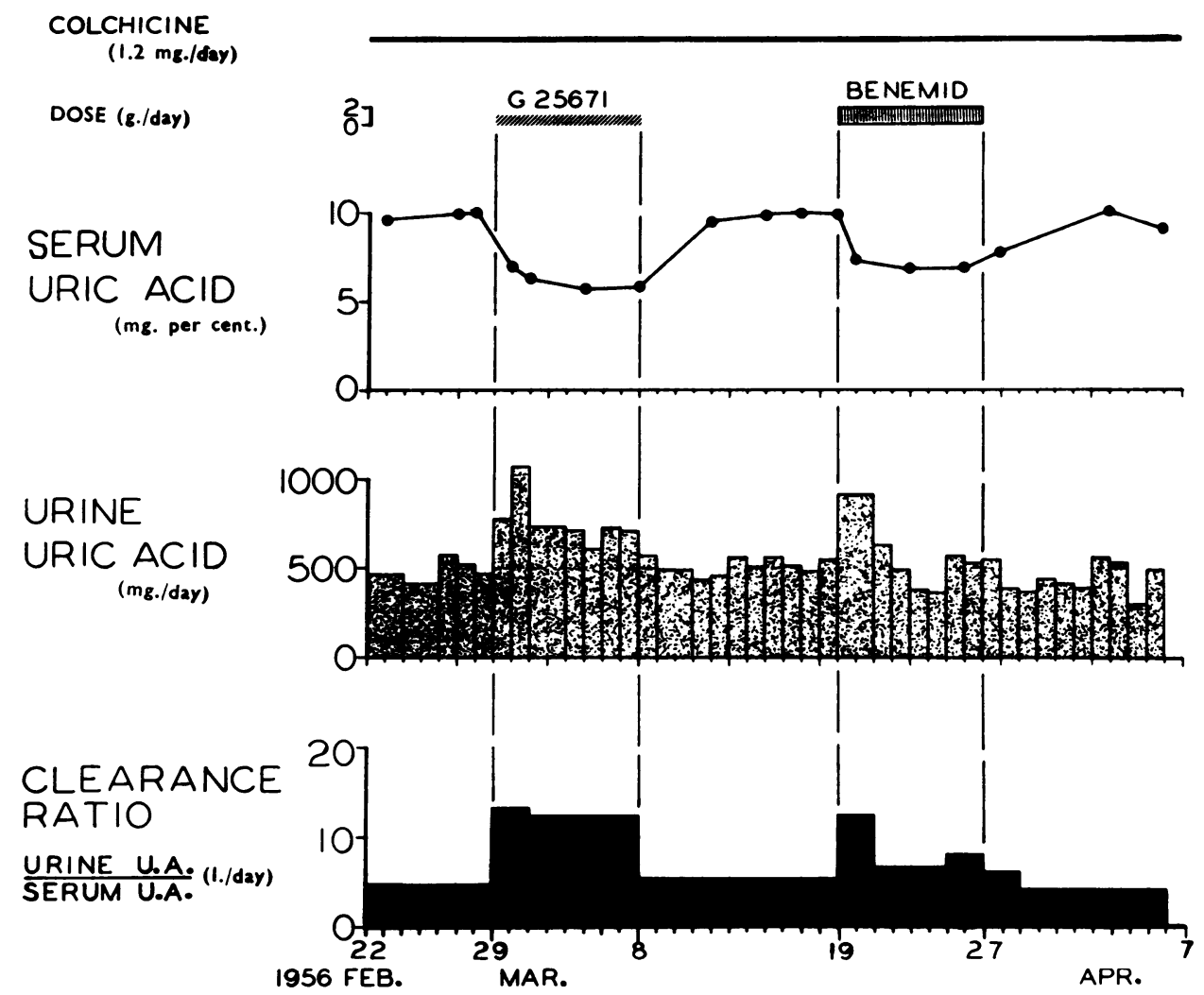

Fig. 2.-Comparison between the uricosuric effects of $1 \mathrm{~g}$. G25671 daily for 8 days and $2 \mathrm{~g}$. Benemid. daily for 8 days.

In a fourth patient (Fig. 4, overleaf, p. 430) the effects of $1 \mathrm{~g}$. G25671 daily were compared with Benemid 1, 2, and $3 \mathrm{~g}$. daily, each for 8 days with control periods of 8 to 12 days between courses. Again, on the basis of serum uric acid values, total urine uric acid excretion, and clearance ratio, $1 \mathrm{~g}$. G25671 daily was found to be as effective or perhaps slightly more effective than $3 \mathrm{~g}$. Benemid daily, suggesting that it was three times as potent a uricosuric agent, per unit of weight.

The fifth study (Fig. 5, overleaf, p. 431) shows a comparison of a number of known uricosuric agents, in doses that were designed to give a comparable uricosuric effect. On the basis of decrease in the serum uric acid and clearance ratio, it will be seen that the effects were roughly comparable with the administration of $1 \mathrm{~g}$. phenylbutazone daily (serum uric acid decrease from 9.8 to $2.9 \mathrm{mg}$. per cent. in 8 days), 6 g. acetylsalicylic acid daily (serum uric acid decrease from 8.3 to $2.7 \mathrm{mg}$. per cent. in 8 days), 1 g. G25671 daily (serum uric acid decrease from 7.0 to $2.0 \mathrm{mg}$. in 6 days), and $3 \mathrm{~g}$. probenecid daily (serum uric acid decrease from 6.6 to $2.5 \mathrm{mg}$. per cent. in 8 days). However, on the basis of the data obtained, $200 \mathrm{mg}$. G28315 daily (serum ur $\overrightarrow{\mathrm{k}}$ acid decrease from 6.5 to $3.4 \mathrm{mg}$. per cent. in 8 days and $900 \mathrm{mg}$. Tromexan daily (serum uric aci decrease from 7.0 to $4.0 \mathrm{mg}$. per cent. in 8 days were somewhat less effective. The dose of $200 \mathrm{mg}$ G28315 daily was chosen on the basis of datig obtained from the manufacturer, ${ }^{*}$ but proved to be too low. The marked increase in urinary uric acid excretion obtained with acetylsalicylic acid was rather surprising. Urinary nitrogen studies done on this patient showed a slight but definite negative nitrogen balance during this period. It is als known that some of the salicylate may be excrete as gentisic acid which is measured in the uric acias determinations (Yü and Gutman, 1949; Pascale andb others, 1952). Unfortunately, preliminary extra\&

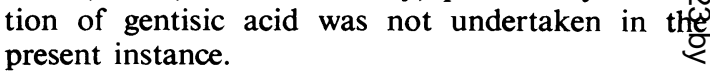

In order to obtain a closer approximation of the uricosuric effect of the newer G28315, the druts

- Basic Data, G28315-Uricosuric Agent, Geigy Pharmaceuticals Division of Geigy (Canada) Ltd., Montreal, Canada. 


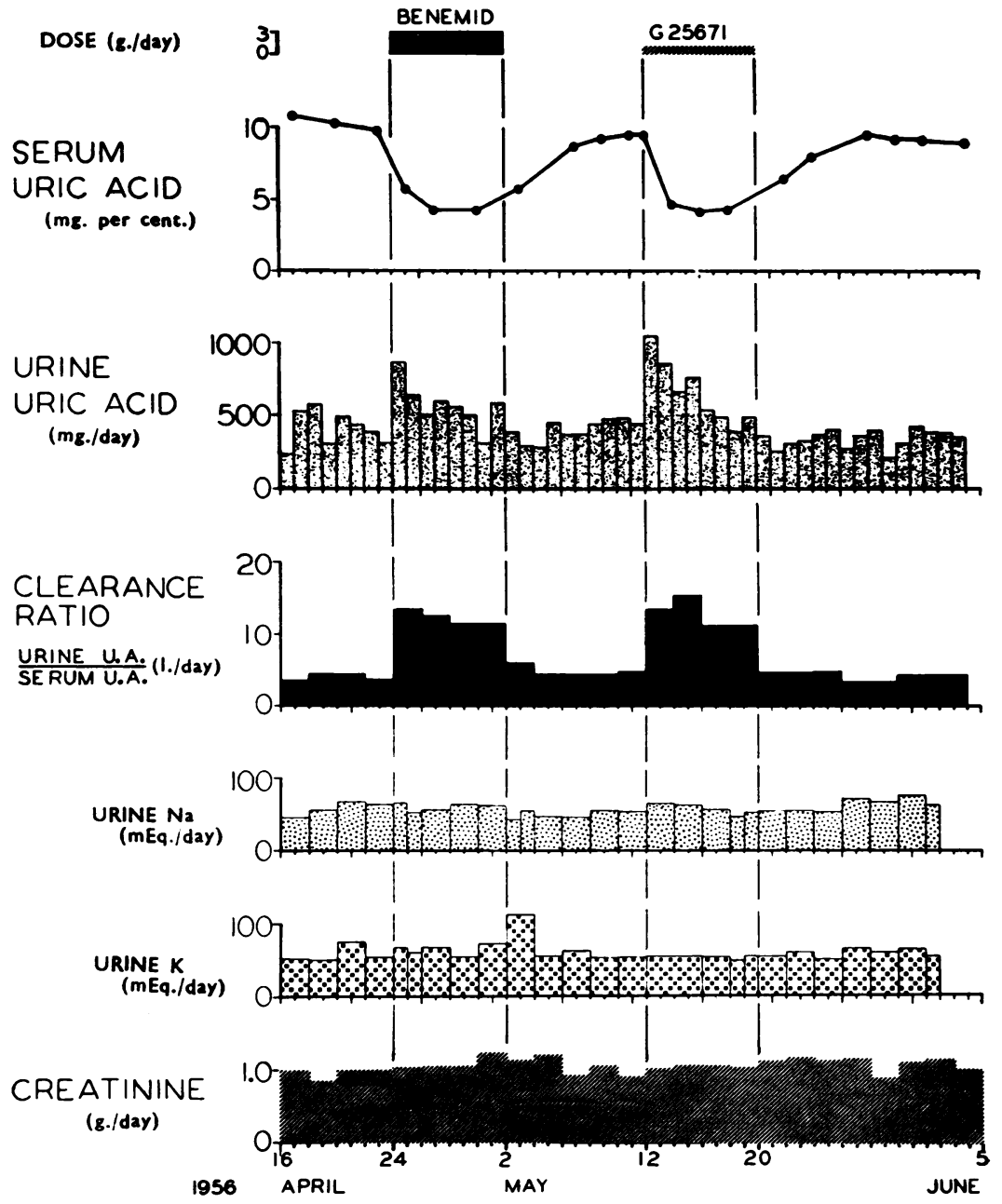

Fig. 3.-Comparison between the uricosuric effects of $3 \mathrm{~g}$. Benemid daily for 8 days and $1 \mathrm{~g}$. G25671 daily for 8 days.

was given to the first patient studied (Fig. 1), this time in doses of $500 \mathrm{mg}$. daily (Fig. 6, overleaf, p. 432). A dose of $500 \mathrm{mg}$. daily was selected on the basis of preliminary trials in the general medical service. At this dosage the uricosuric effect of G28315 was comparable to that previously obtained with $1 \mathrm{~g}$. daily of the older G25671. It would suggest that G28315 has at least twice the uricosuric activity of the older G25671 and six times the uricosuric activity of probenecid, per unit of weight.

Data illustrating the comparative effectiveness of these different uricosuric agents, obtained from a total of 81 trials in 41 patients with gout, during a 12-month period, are shown in composite scattergrams (Figs 7 and 8, overleaf, p. 433). The maximum serum uric acid decrease (Fig. 7), expressed as a percentage of the control values, indicates roughly a comparable effect obtained with 1 g. G25671 daily (mean drop 57 per cent.), 6 g. acetylsalicylic acid daily (mean drop 52 per cent.), 1 g. phenylbutazone daily (mean drop 50 per cent.), and 0.5 g. G28315 daily (mean drop of 51 per cent.). The uricosuric effect of $3 \mathrm{~g}$. probenecid daily was slightly less (mean drop 44 per cent.) and distinctly less with smaller doses. The sustained effect (Fig. 8) over more prolonged periods of 3 to 12 months was much the same. Approximately comparable effects were observed with 1 g. G25671 daily, 1 g. phenylbutazone daily, and $0.5 \mathrm{~g}$. G28315 daily. Acetylsalicylic acid $6 \mathrm{~g}$. daily and probenecid 2 or $3 \mathrm{~g}$. daily were slightly less effective in the long-term trial. While the number of patients in some of the groups was small and there 


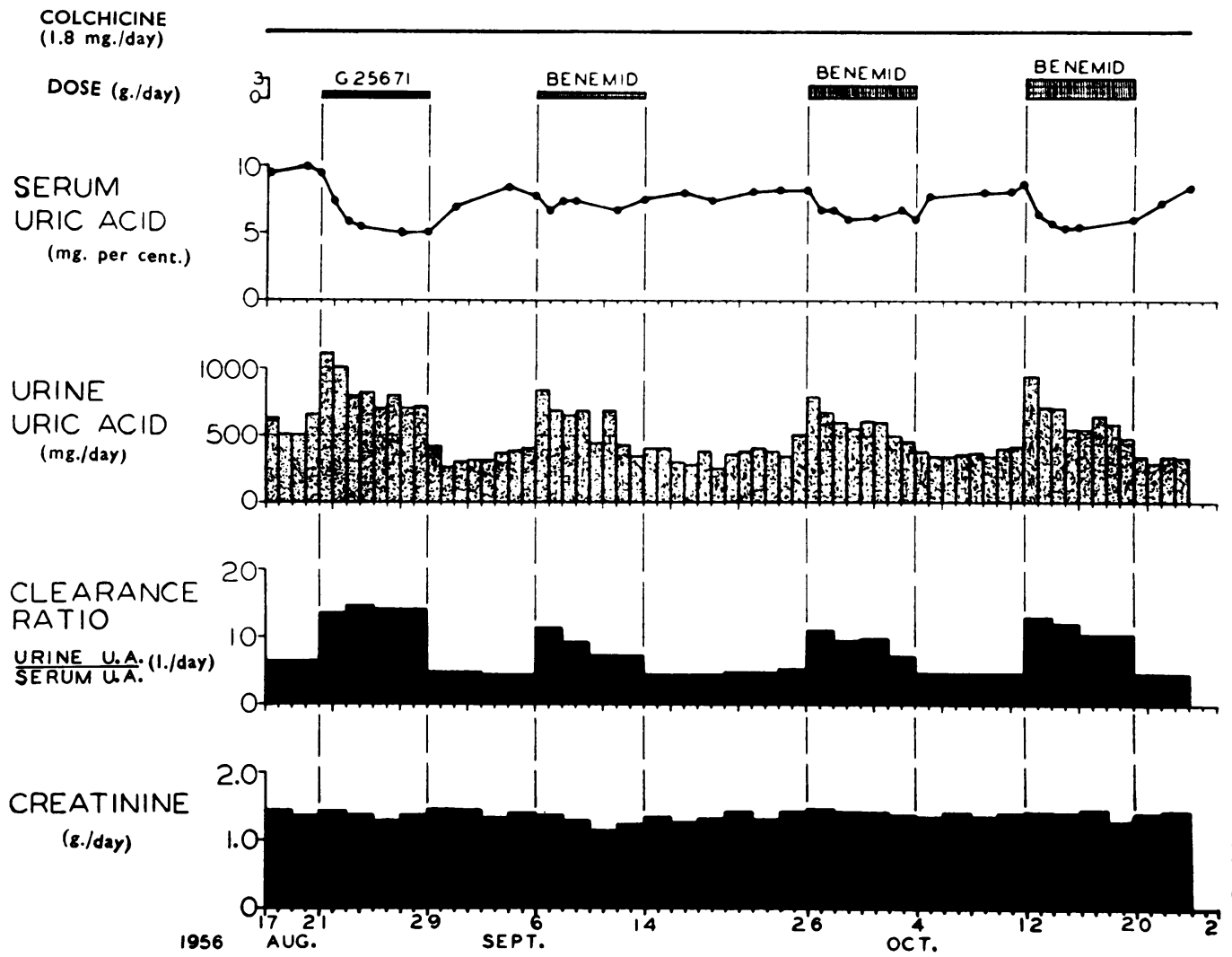

Fig. 4.-Comparison between the uricosuric effects of $1 \mathrm{~g}$. G25671 daily for 8 days and Benemid 1 , 2 . and $3 \mathrm{~g}$. daily for periods of 8 days, separated by control periods of 8 to 12 days between courses.

were obvious individual variations in reactions to each drug, nevertheless the general trend and potency of uricosuric action are evident. The average mean value for serum uric acid in a group of 23 patients receiving $1 \mathrm{~g}$. G25671 daily for periods of 3 to 12 months, was $4.7 \mathrm{mg}$. per cent. This included two patients with some degree of renal insufficiency (non-protein-nitrogen up to $70 \mathrm{mg}$. per cent.). In no instance did the mean value exceed $6 \mathrm{mg}$. per cent.

In many patients, prolonged therapy with probenecid has been very satisfactory, even in doses as low as 1 g. daily. Fig. 9 (overleaf, p. 434) shows one such instance, in which the serum uric acid was maintained for the most part below the upper limit of normal of $6 \mathrm{mg}$. per cent., for approximately 4 years. Chronic joint symptoms improved considerably during this period, although the patient continued to have sporadic mild attacks of acute gouty arthritis. Not infrequently, however, 1 g. probenecid daily may not be adequate to bring the serum uric acid within the normal range. Larger doses of 2 or $3 \mathrm{~g}$. daily are usually more effective, but are more likely to cause gastro-intestinal $\overrightarrow{\overrightarrow{0}}$ symptoms. Many of those treated with G25671 fell into this category, and in all instances the administration of 1 g. G25671 daily was strikingly more effective (Fig. 10, overleaf, p. 434). Thus far the administration of G25671 to patients with uncompli- $\frac{\circ}{\circ}$ cated gout in the doses specified has maintained the 3 serum uric acid consistently within the normal range (Fig. 11, overleaf, p. 435) for periods up to one year. $₹$ G25671 was distinctly more effective than probenecid, 응 even in patients with renal complications and some degree of nitrogen retention who did not respond $\frac{}{0}$ quite so dramatically. In such cases no further impairment of renal function nor any significant or improvement has been observed. The reduction in N erythrocyte sedimentation rate with the institution of N therapy (Fig. 11, overleaf, p. 435) has been attributed ${ }_{\sigma}^{\omega}$ to quiescence of the gouty manifestations, since the drug does not appear to have potent anti-inflammatory properties. For example, in a patient with rheumatoid arthritis (Fig. 12, overleaf, p. 435), G25671 had no effect on joint pain or on the 

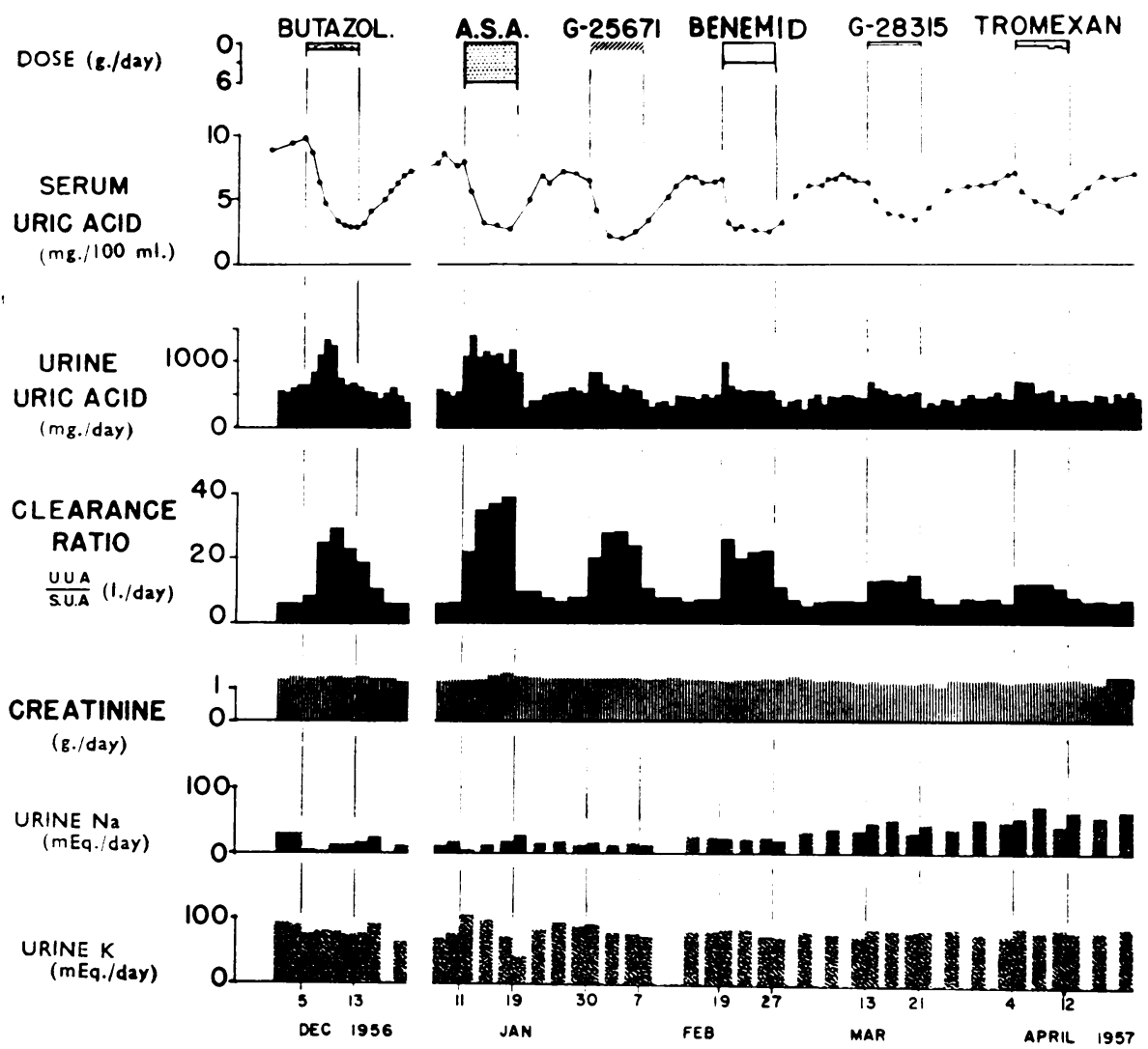

Fig. 5.-Comparison between the uricosuric effects of Butazolidin 1 g. daily, acetylsalicylic acid $6 \mathrm{~g}$. daily. G25671 $1 \mathrm{~g}$. daily, Benemid $3 \mathrm{~g}$. daily, G28315 $200 \mathrm{mg}$. daily, and Tromexan $900 \mathrm{mg}$. daily, all for periods of 8 days separated by control periods of 12 days.

erythrocyte sedimentation rate, but it exhibited an excellent uricosuric action. Butazolidin exhibited a good analgesic effect and variable uricosuric action depending on the dose given, but had no effect on the erythrocyte sedimentation rate. Prednisone (Meticorten), on the other hand, exhibited good analgesic properties, poor uricosuric action, and a good anti-inflammatory effect, as indicated by the prompt fall in the erythrocyte sedimentation rate.

A paradoxical retention of uric acid has been shown to occur when known uricosuric agents such as salicylates, probenecid, phenylbutazone, or the phenylbutazone analogues are administered in low dosage (Klemperer and Bauer, 1944: Yü and Gutman, 1955). Furthermore, it is known that small doses of salicylates, inadequate in themselves to exhibit uricosuric effect, will tend to block the uricosuric action of probenecid (Gutman and Yü, 1952: Pascale and others, 1952). It was of interest in the present study to note that small doses of salicylates administered together with either of the two phenylbutazone analogues similarly blocked the uricosuric action of the latter. On the other hand, there does not appear to be any blocking effect of probenecid, phenylbutazone, or the phenylbutazone analogues when used in combination with one another ( $Y \ddot{u}$ and others, 1953). It is important therefore, to remember that salicylates must not be administered, even in small doses, while the patient is under treatment with probenecid or the newer phenylbutazone analogues (G25671 and G28315).

\section{Discussion}

Uricosuric Action.-In view of the fact that the long-term management of patients with chronic gouty arthritis is currently directed toward reducing the level of the serum uric acid by increasing urinary excretion and thereby reducing the total miscible pool, the search for more effective uricosuric agents would appear to be justified. In the past 7 years this role has been occupied almost exclusively by probenecid, a relatively non-toxic drug. However, many patients are not adequately controlled on doses 


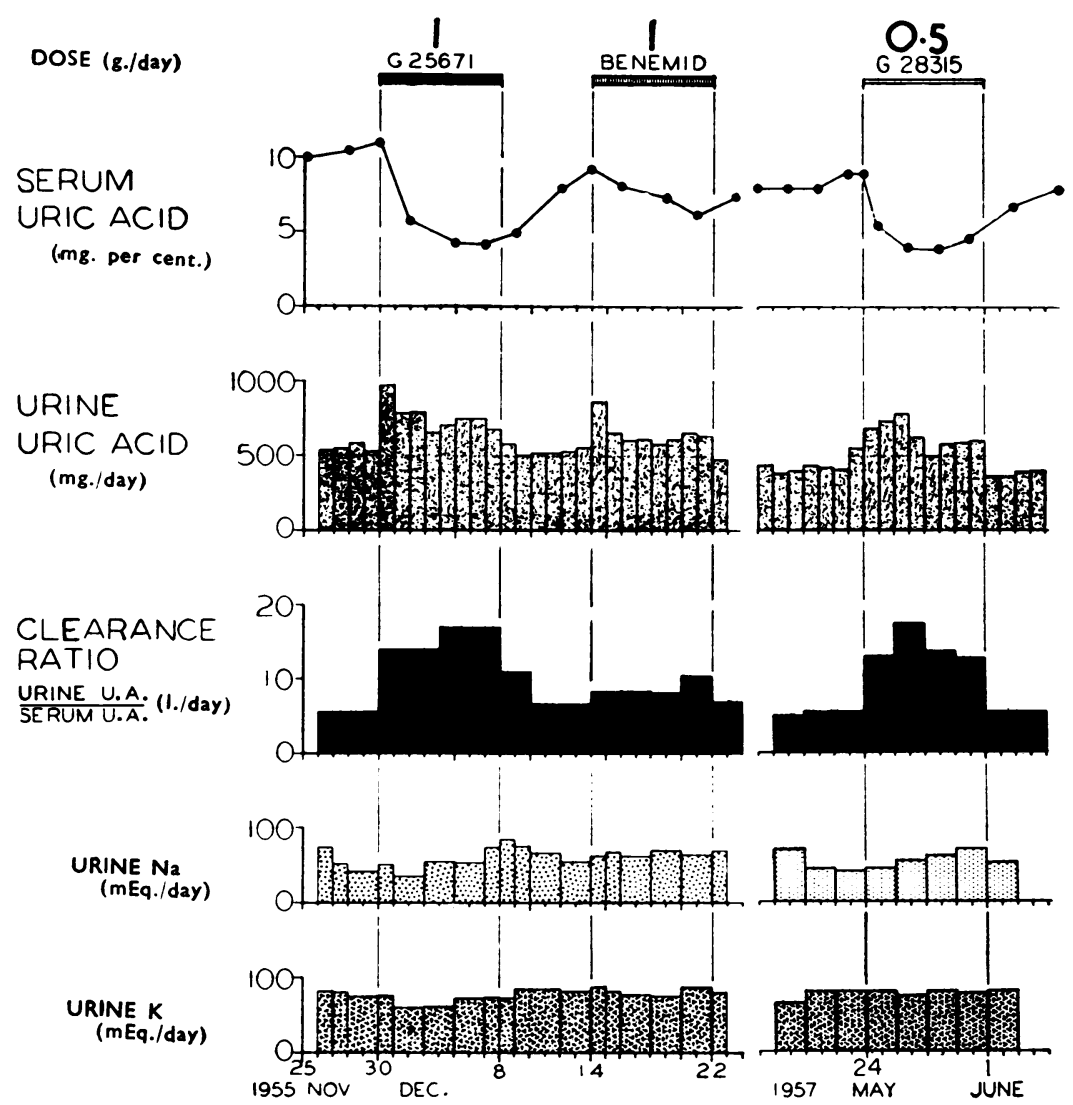

Fig. 6.-Comparison between the uricosuric effects of G25671 and Benemid and those of G28315 (0.5 g. daily) in the same patient after an interval of 16 months (compare Fig. 1).

that are well tolerated and may continue to have recurring attacks of acute gouty arthritis. For this reason it has been recommended that the administration of probenecid be combined with suppressive doses of colchicine, varying from 0.5 to $1.5 \mathrm{mg}$. daily (Talbott, 1953; Gutman and Yü, 1955; Bartels, 1955; Bauer and Singh, 1957). Salicylates have been less popular, partly because of the large doses required but more particularly because of the high incidence of gastric intolerance or other sideeffects. Apart from its tendency to induce salt retention and its reported toxicity, phenylbutazone would appear to have considerable merit. It exhibits excellent uricosuric action, has analgesic properties, and is ideal for suppression and treatment of the acute attacks of gouty arthritis. Indeed, some workers (Kuzell and others, 1954, 1955) believe it to be the best agent yet available for this purpose. The addition of colchicine in maintenance doses thus becomes unnecessary. Furthermore, because its action is delayed and more prolonged than that of other uricosuric agents (Yü and others, 1956), the omission of the medication for a few days at a time would not be a serious matter.

Two new uricosuric agents, both derivatives of phenylbutazone, have been subjected to trials in a $\overline{0}$ small group of patients with encouraging results. G25671 was shown to be approximately three times and G28315 approximately six times as potent as probenecid, per unit of weight. The optimum dose 윽 for maximum uricosuric effect was found to be $D$ 1 g. G25671 daily and 0.5 g. G28315 daily. No 을 loss of uricosuric effect was noted with prolonged $\bar{N}$ administration (up to 12 months in the case of 0 G25671 and 4 months in the case of G28315). The $N$ duration of action of both drugs was somewhat $\underset{\omega}{\mathrm{N}}$ less than with phenylbutazone, being approximately equal to that of probenecid, and the omission 0

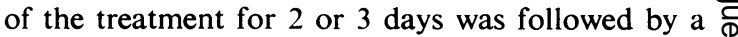
prompt rise in the serum uric acid level. The $\stackrel{0}{?}$ greater effectiveness of these drugs over that of 0 probenecid and their ability to reduce the serum 

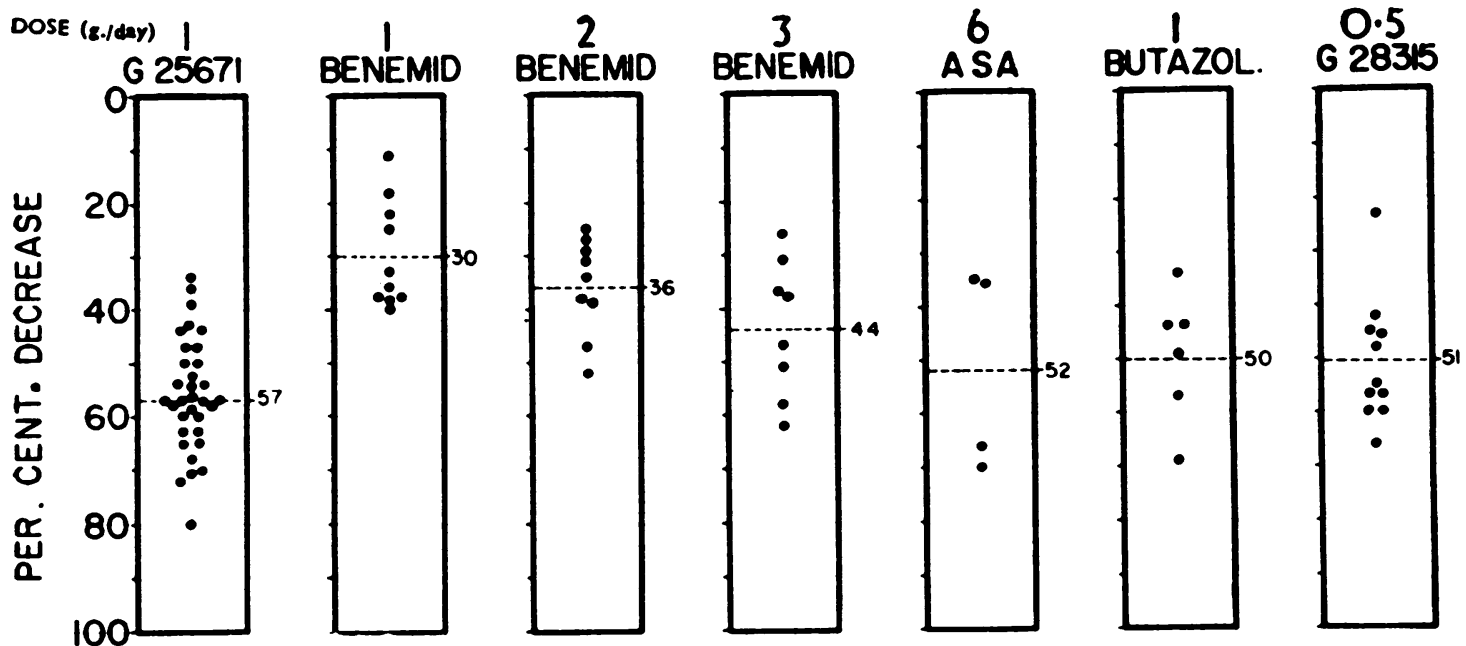

Fig. 7.-Maximum serum uric acid decrease in 81 trials in 41 patients with gout under treatment with G25671, Benemid, acetylsalicylic acid, Butazolidin, and G28315, shown as a percentage decrease from the control value.

DOSE (z./day)

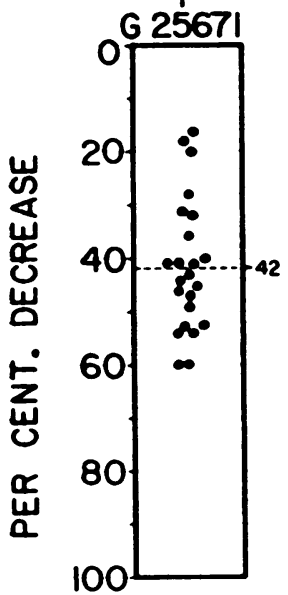

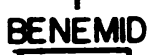

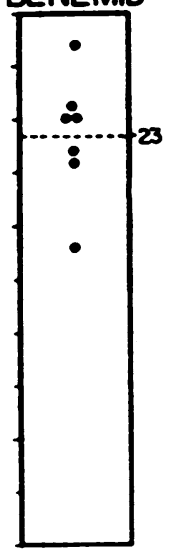

3

6
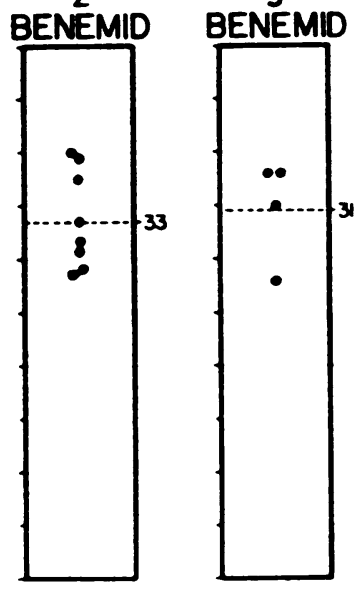
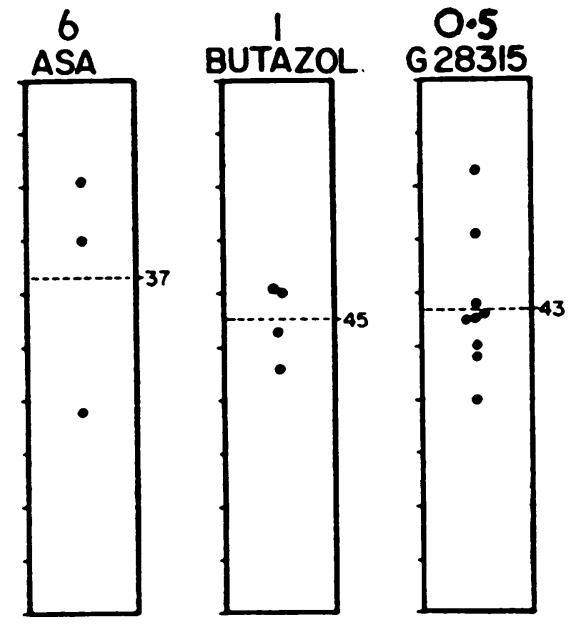

Fig. 8. - Sustained serum uric acid decrease in 58 trials in 35 patients with gout under treatment with the same drugs as shown in Fig. 7 but over more prolonged periods, shown as a percentage decrease from the control value.

uric acid to normal values was observed even in the presence of impaired renal function and with a moderate degree of nitrogen retention. Neither agent exhibited any significant effect on sodium or potassium excretion.

The uricosuric action of ethyl biscoumacetate (Tromexan) (Sougin-Mibashan and Horwitz, 1955) is of academic interest only, since its effect on the blood-clotting system precludes its use as a treatment measure in gout. In the one patient to whom Tromexan was administered, it appeared to be at least as effective as a uricosuric agent as probenecid.

Clinical Response.-Improvement in the clinical symptoms and manifestations of chronic gout was observed with all agents which exhibited uricosuric action. Ethyl biscoumacetate and phenylbutazone, however, are not suitable for this purpose, for reasons already mentioned. Salicylates, in the doses necessary for good uricosuric action, were not tolerated for more than 3 months. Of the four patients so treated, two developed tinnitus with deafness and one complained of severe gastric irritation. In general, probenecid was well tolerated by those patients in whom a good uricosuric effect was obtained with doses of 1 to $1.5 \mathrm{~g}$. daily. In most of these patients colchicine was administered concurrently in suppressive doses of 1 to $1.5 \mathrm{mg}$. daily. Chronic symptoms of stiffness and aching in various joints persisted in many patients though 


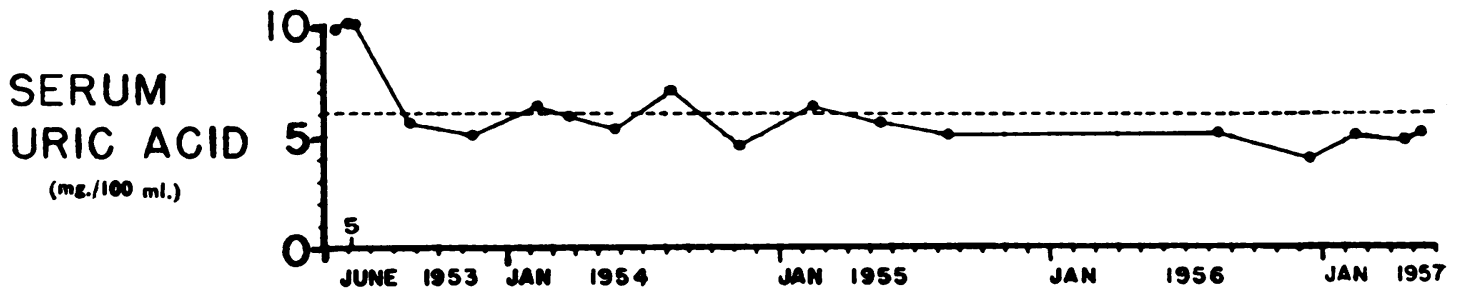

Fig. 9.-Effects of prolonged therapy with Benemid $1 \mathrm{~g}$. daily in a patient with chronic gout for a period of 4 years.

DOSE (8./day)
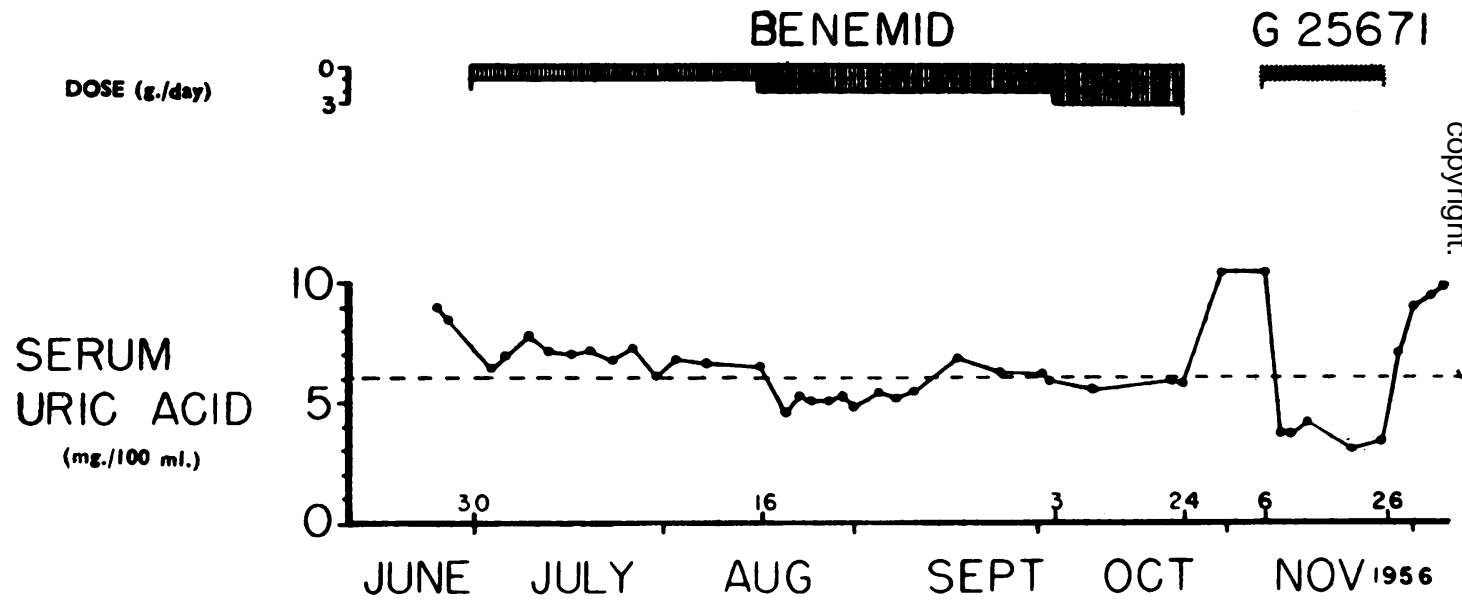

Fig. 10.-Effect of 1 g. G25671 daily compared with that of Benemid in a patient with chronic gout for a period of 6 months.

somewhat subdued, and sporadic attacks of acute gouty arthritis continued though less severe and less frequent than before the institution of treatment. Where larger doses of 2 or $3 \mathrm{~g}$. daily were necessary to achieve a good uricosuric effect, toxic manifestations were more frequent. These consisted mainly of gastric irritation, dermatitis, or urticaria.

The patients treated with the newer drugs, G25671 and G28315, comprised either newly-admitted patients who had not previously been treated with uricosuric agents, or patients in whom therapy with probenecid was unsatisfactory. The latter were drawn from a larger group of patients on long-term probenecid therapy, not included in this study, in whom the treatment was discontinued for the following reasons:

(i) Unsatisfactory uricosuric effect in six;

(ii) Gastric intolerance to the drug in five;

(iii) Urticaria or skin eruptions in two.

G25671 was administered to 25 patients in 33 N separate therapeutic trials, for periods up to $12 \mathrm{\omega}$ months (average 6 months). The drug was well? tolerated by all patients with no indication of gastric irritation. A mild maculopapular rash appeared in three patients during the first 6 weeks of therapy, but it subsided after 2 or 3 days with the adminis- 
THERAPY

COLCHICINE $(1.2 \mathrm{mg} . / \mathrm{dar})$

\section{G-25671 (1 8./dar)}

AT TACKS

BUTAZOLIDIN (0.4 \&Jday)

SERUM
URIC ACID
$(\mathbf{m g} .1100 \mathrm{ml}$.

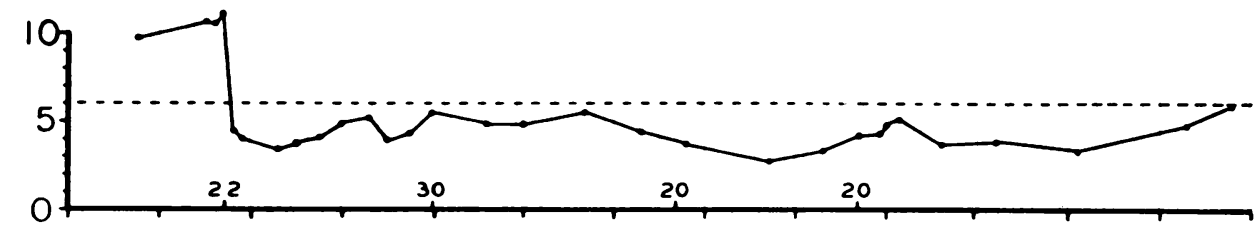

E.S.R.

(mm./hr)

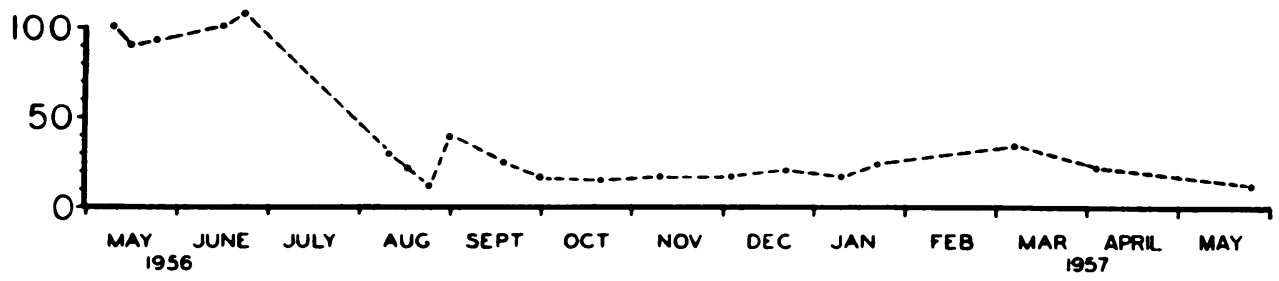

Fig. 11.-Serum uric acid levels in a patient receiving 1 g. G25671 daily for 12 months.

THERAPY

(dose per day)

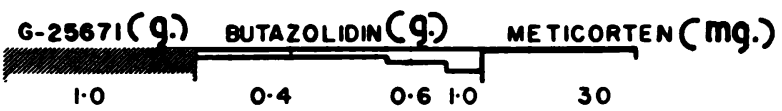

PAIN
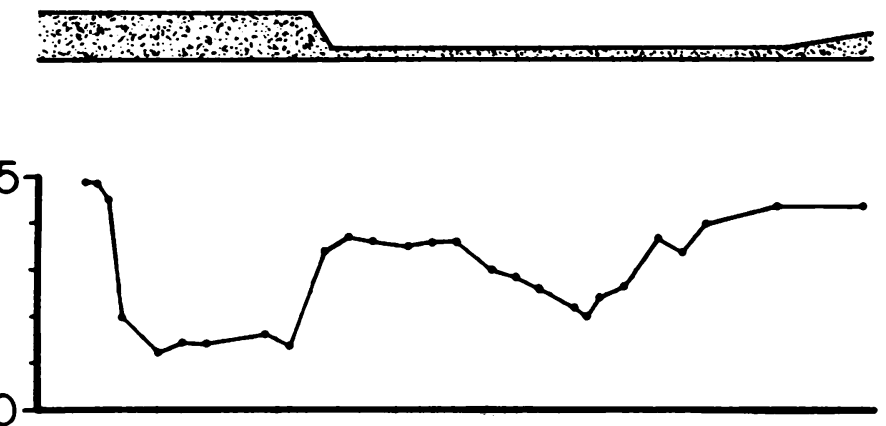

E.S.R.

(mm./hr.)

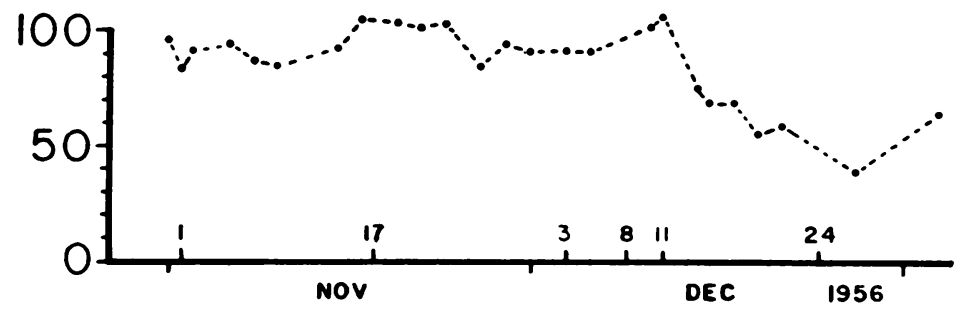

Fig. 12.-Comparison of the effects of G25671, Butazolidin, and Meticorten in a patient with rheumatoid arthritis for a period of 2 months. 
tration of pyribenzamine and did not recur despite continuation of G25671. No other toxic manifestations were noted, although the white cell count was depressed slightly in several patients. Invariably, the uricosuric response was greater than that to probenecid in the ratio of 3 to 1 per unit of weight. One patient who had previously experienced aggravation of acute attacks with probenecid, also experienced four attacks of severe acute gouty arthritis during the first 6 weeks of G25671, even with the addition of $1 \cdot 2 \mathrm{mg}$. colchicine daily, and five other patients experienced from one to three mild attacks during the first month of treatment. For this reason suppressive doses of colchicine were used at the commencement of treatment, especially in patients prone to frequent attacks of acute gouty arthritis. However, acute attacks were completely suppressed in all the remaining patients after therapy with G25671 was begun. All patients noted progressive improvement in chronic stiffness and pain, increased strength, energy, and general sense of well being, to a degree not previously observed with probenecid. In general, the greatest improvement was noted in those patients in whom the serum uric acid was maintained well below the upper range of normal. This rather striking improvement made it possible to discontinue the practice of combined therapy with suppressive doses of colchicine after the serum uric acid had been depressed to normal values for approximately 4 to 6 weeks, without the precipitation of further acute attacks of gouty arthritis.

The group of eleven patients treated with G28315 is too small and the period of therapy too short for adequate evaluation. Thus far, however, the clinical improvement and uricosuric action observed with $0.5 \mathrm{~g}$. daily of the newer analogue have been comparable to that obtained with $1 \mathrm{~g}$. daily of G25671. No toxic effects have been observed. In view of the smaller doses required, it is possible that this enhanced action of the drug may lessen the risk of toxic manifestations with more prolonged administration.

During the relatively short period of this study, no significant changes were noted in the size of visible tophaceous deposits. There was no instance of calculus formation and no further impairment of pre-existing renal damage with any of the forms of therapy used.

\section{Summary}

A comparative evaluation has been made of a number of known uricosuric agents in the treatment of patients with gout, including probenecid (Benemid), phenylbutazone (Butazolidin), thiophenylpyrazolidine (G25671), sulphoxyphenylpyrazolidine
(G28315), acetyl salicylic acid (Aspirin), and ethyl biscoumacetate (Tromexan). The uricosuric effect, suppression of recurring attacks of acute gouty arthritis and clinical improvement in the chronic gouty manifestations were distinctly superior with the two new phenylbutazone derivatives, G25671 and G28315. Per unit of weight, they were respectively about three and six times as potent as probenecid, both in lowering the level of the serum uric acid and in increasing the urinary excretion of is uric acid. This uricosuric action appeared to be well sustained over prolonged periods of 3 to 12 months. No serious toxic manifestations were noted in the group of patients studied, although this possibility must be kept in mind, particularly in regard to the wider application of the phenyl- $\vec{\sigma}$ butazone analogues in the treatment of chronic gout.

Grateful acknowledgment is made to Prof. J. A. 음 Dauphinee and Prof. A. G. Gornall for their co-opera- tion in the study; to Dr. Wallace Graham and Dr. D. C. Graham for access to patients on their service; to Mrs. J. Rose for the many uric acid determinations; and to the $\frac{\mathbb{S}}{3}$ Department of Photography, Sunnybrook Hospital, for $\frac{7}{0}$ the photographic reproductions of the charts. The authors are indebted to Geigy Pharmaceuticals, Division $\vec{\omega}$ of Geigy (Canada) Ltd., Dr. P. B. Stewart, Mediç Director Montreal, Canada, for a grant-in-aid in suppoft. of the study, and for generous supplies of G25671 ang G28315.

\section{REFERENCES}

Bartels, E. C. (1955). Ann. intern. Med., 42, 1. New. J. Med., 231, 681. 文 Bauer, W., and Klemperer, F. (1944). New Engl.

Benedict, J. D., Forsham, P. H., Roche, M., Soloway, S., and $\overrightarrow{\bar{O}}$ Stetten, D., Jr. (1950). J. clin. Invest., 29, 1104.

Bishop, C., and Beecher, L. (1953). Proc. Soc. exp. Biol. (N.Y.), 83, 603 .

Boger, Rand, R., and Talbott, J. H. (1951). J. clin. Invest., 30, 889. 95, 83 .

Brodie, B. B., Lowman, E. W., Burns, J. J., Lee, P. R., Chenkin, T., ฏ Goldman, A., Weiner, M., and Steele, J. M. (1954a). Amer. J. Med., 16, 181 .

Yü, T. F., Burns, J. J., Chenkin, T., Paton, B. C., Steele, J. M., Oَ and Gutman, A. B. (1954b). Proc. Soc. exp. Biol. (N.Y.), 86, 884 .

Burns, J. J., Yü, T. F., Ritterband, A., Perel, J. M., Gutman, A. B., Oุ and Brodie, B. B. (1957). J. Pharmacol., 119, 418.

Gutman, A. B. (1950). Amer. J. Med., 9, 799.

- and Yü, T. F. (1951). Trans. Ass. Amer. Phys., 64, 279.

- - (1952). Amer. J. Med., 13, 744.

- - (1955). J. Amer. med. Ass., 157, 1096

- and Randolph, V. (1954). Trans. Ass. Amer. Phys., $\frac{D}{O}$

Jennings, G. H. (1937). “Reports on Chronic Rheumatic Diseases", No. 3, p. 106. Lewis, London.

Kern, A., and Stransky, E. (1937). Biochem. Z., 290, 419

Klemperer, F., and Bauer, W. (1944). J. clin. Invest., 23, 950.

Kuzell, W. C., Schaffarzick, R. W., Naugler, W. E., Gaudin, G., Mankle, E. A., and Brown, B. (1954). Amer. J. Med., N 16, 212.

Schaffarzick, R. W., Naugler, W. E., Koets, P., Mankle. E. A..ర Brown, B., and Champlin, B. (1955). J. chron. Dis., 2, 645.

Marson, F. G. W. (1952). Brit. J. Radiol., 25, 539.

Marson, F. G. W. (1952). Brit. J. Radid

(1954). Quart. J. Med., 22, 331.

(1955). Lancet, 2, 360

Mauer, E. F. (1955). New Engl. J. Med., 253, 404.

Pascale, L. R., Dubin, A., and Hoffman, W. S. (1952). J. Amer. T med. Ass., 149, 1188 . 
Sirota, J. H., Yü, T. F., and Gutman, A. B. (1952). J. clin. Invest., $31,692$.

Sougin-Mibashan, R., and Horwitz, M. (1955). Lancet, 1, 1191.

Talbott, J. H. (1953). "Gout and Gouty Arthritis." Modern Medical Monographs, No. 7. Grune and Stratton, New York. Bishop, C., Norcross, B. M.. and Lockie, L. M. (1951). Trans. Ass. Amer. Phys., 64, 372

Wilson, G. M., Jr., Huffman, E. R., and Smyth, C. J. (1956). Amer. J. Med., 21, 232

Wyngaarden, J. B. (1955). J. clin. Invest., 34, 256.

Yü, T. F., and Gutman, A. B. (1949). Fed. Proc., 8, 267. (1951). Amer. J. Med., 11, 765. Proc. Soc. exp. Biol. (N.Y.), 90, 542.

二, Paton, B. C., Chenkin, T., Burns, J. J., Brodie, B. B., and Gutman, A. B. (1956). J., clin. Invest., 35, 374.

- C, Sirota. J. H., and Gutman, A. B. (1953). Ibid., 32, 1121.

\section{Evaluation des agents uricosuriques dans la goutte chronique}

\section{RÉSUMÉ}

On a fait une évaluation comparative de plusieurs agents uricosuriques connus dans le traitement de la goutte: probénécide (Bénémide), phénylbutazone (Butazolidine), thiophénylpyrazolidine (G25671), sulfoxyphénylpyrazolidine (G28315), acide acétylsalicylique (Aspirine), et ethyl-biscoumacetate (Tromexan). L'effet uricosurique, la suppression d'attaques récurrentes d'arthrite goutteuse auguë et l'amélioration clinique des manifestations goutteuses chroniques, étaient nettement supérieurs avec les deux nouveaux dérivés du phénylbutazone, le G25671, et le G28315. Par unité de poids, ils étaient respectivement trois et six fois plus puissants que le probénécide pour abaisser le niveau d'acide urique dans le sérum et pour l'augmenter dans l'urine. Cette action uricosurique paraissait bien se souteinir sur des périodes prolongées de 3 à 12 mois. Aucune manifestation toxique sérieuse ne fut notée dans le groupe de malades étudiés, bien qu'il faille garder leur possibilité à l'esprit, en particulier en ce qui concerne l'emploi plus généralisé des analogues du phénylbutazone dans le traitement de la goutte chronique.

\section{Valoración de los agentes uricosúricos en la gota crónica \\ SUMARIO}

Varios agentes uricosúricos empleados en el tratamiento de la gota fueron avalorados comparativamente: probenecid (Benemid), fenilbutazona (Butazolidina), tiofenilpirazolidina (G25671), sulfoxifenilpirazolidina (G28315), ácido acetilsalicílico (Aspirina), y etil-biscoumacetato (Tromexan). El efecto uricosúrico, la supresión de ataques recurrentes de artritis gotosa aguda y la mejoría clínica de las manifestaciones gotosas crónicas fueron netamente superiores con los dos nuevos derivados de la fenilbutazona, el G25671, y el G28315. A peso igual, éstos fueron respectivamente tres y seis veces más poderosos que el probenecid en su capacidad de hacer bajar el ácido úrico en el suero y aumentar su excreción urinaria. Esta acción uricosúrica pareció mantenerse durante períodos prolongados de 3 a 12 meses. En el grupo de los enfermos estudiados no se notaron manifestaciones tóxicas serias, pero se debe estar alerta a su posibilidad, al considerar el empleo más general de los análogos de la fenilbutazona en el tratamiento de la gota crónica. 